\title{
Research Article \\ Effects of Different Enzymes and Concentrations in the Production of Clarified Lemon Juice
}

\author{
Filiz Uçan, ${ }^{1}$ Asiye Akyildiz, ${ }^{2}$ and Erdal Ağçam ${ }^{2}$ \\ ${ }^{1}$ Food Engineering Department, Engineering Faculty, Kilis 7 Aralı University, 79000 Kilis, Turkey \\ ${ }^{2}$ Food Engineering Department, Agricultural Faculty, Cukurova University, 01330 Adana, Turkey \\ Correspondence should be addressed to Filiz Uçan; ucanfiliz@gmail.com
}

Received 22 January 2014; Revised 13 April 2014; Accepted 28 April 2014; Published 1 June 2014

Academic Editor: Dike O. Ukuku

Copyright (C) 2014 Filiz Uçan et al. This is an open access article distributed under the Creative Commons Attribution License, which permits unrestricted use, distribution, and reproduction in any medium, provided the original work is properly cited.

\begin{abstract}
Lemon juice obtained from Interdonato variety was treated with different enzymes at specific concentrations as depectinization processes to produce clear lemon juice and its concentrates. In addition, the best condition obtained from laboratory treatments was carried out in the local fruit juice plant. Effects of the processing steps on some quality parameters were investigated during the lemon juice production and the obtained concentrates were stored at $-25^{\circ} \mathrm{C}$ for 180 days. The results showed that Novozym 33095 had the best depectinization effectiveness. Total pectin content of lemon juices decreased rapidly following the enzyme treatment and could not be detected following the filtration. Viscosity values decreased after pulp separation and the largest reduction was observed with the filtration. At the end of filtration in $40 \mu \mathrm{L} / 100 \mathrm{~mL}$ concentrations of each of the three enzymes, values of residual pectinmethylesterase (PME) activity were found to be in the lowest amounts.
\end{abstract}

\section{Introduction}

Citrus is one of the most important fruit crop in the world. Lemons ranked third among the citrus industry in the world, with a total annual production of about $9 \%$ in the citrus production [1]. Lemons are cultivated in many countries all over the world (13861411 ton) and Turkey ranked the sixth in the production of lemon (790211 ton) in 2011 [2].

The lemon (Citrus limon (L.) Burm. f.) has many important natural chemical components, including citric acid, ascorbic acid, minerals, and flavonoids. Although their healthrelated properties have always been associated with their content of vitamin $\mathrm{C}$, it has recently been shown that flavonoids also play a role in this respect. Lemon fruits not only have their delicious flavors but also have their antioxidant capacity with health benefits [3-6].

Lemons are usually earmarked for fresh consumption and for the elaboration of juices, additives, and various other processed products. New alternatives for beverages elaboration may result in a promising use of surplus production [7]. Lemon juice is widely used as an antioxidant natural substitute for the synthetic ascorbic or citric acids (E300 and E330, resp.) [8]. Clarified lemon juice is a suitable acidifying agent that can substitute citric acid and provide more "natural" products that will fit the new market for ecological products and new alternatives to the manufacturing of lemon [9]. Clarified lemon juice can be consumed directly such as fruit juice and also used for production of nectar, jam, marmalade and sweet, lemon sauce in ready to eat meal sector, candy, alcoholic beverages, and acidity regulator in fruit juice and has recently been used as fillings in canned fruits. Saura et al. [9-11] reported that use of lemon juice as a substitute for citric acid in canned fruit, for example, peach halves, will yield a "natural" product for the new market of ecological products.

The traditional method of clarification of juice which contains pectin involves a number of steps, including centrifugation to remove suspended solid, hydrolysis of pectin with specific enzymes (depectinization), flocculation of turbidity with clarifying agents, and finally filtration by the diatomaceous earth to remove the fining agents [12].

Fruit juices contain colloids that are mainly polysaccharides (pectin, cellulose, hemicellulose, lignin, and starch), protein, tannin, and metals. The principal purpose of the clarification process employed in industrial juice processing is to eliminate constituents responsible for the turbidity and cloudiness in freshly produced juice. The key of producing 
clear and stable fruit juice is a complete enzymatic breakdown of pectin. Pectins make the clarification process harder because of their fiber-like molecular structure. Enzymes (particularly pectinases) can play a key role in improving juice clarity and stability as well as reducing the viscosity. The process of depectinization involves the use of commercial enzymes, generally a blend of pectinases (e.g., pectinase, pectinesterase, polygalacturonase, cellulase, and pectin lyase) to degrade pectic substances. These enzymes degrade pectin into smaller units. Pectinase hydrolyzes pectin and causes pectin-protein complexes to flocculate. Polygalacturonase depolymerises the polygalacturonic acid chain via breaking down a-1.4 glycosidic bond, while pectin lyase depolymerises the high esterified (approx. $65 \pm 98 \%$ ) pectin; pectin esterase hydrolyses the methoxy group of the pectin chain. The resulting juice from this pectinase treatment will have a much lower amount of pectin and lower viscosity, which will be advantageous in facilitating the subsequent filtration processes [13].

Clarification is an important processing step used by the lemon juice industry. Clarification is necessary in order to obtain a bright, clear product with low viscosity. Clarification of juice involves the use of bentonite gelatin and silica sol as fining agents. These three components, bentonite, gelatin, and silica sol have successfully been applied for an efficient clarification.

Viscosity is one of the most important physical properties of a fluid system [14]. Viscosity, cloud stability, and other food properties are affected by the impact of pectic enzymes, particularly pectinmethylesterase (PME), a ubiquitous enzyme in plants, that deesterifies the methoxylated pectin in the plant cell wall. PME is released into juice during extraction. PME hydrolyses ester bonds of pectin in citrus juices, resulting in decreased cloud stability [15]. Pectin is responsible for the turbidity and consistency of the juice causing an increase in its viscosity, which hinders its clarification, filtration, and concentration [16].

The aim of this research was to replace citric acid with natural lemon juice, an acidifier perceived by the consumers as a more natural or ecological additive. In this study, lemon juice obtained from Interdonato variety was treated with three different enzymes (Rapidase Intense, Novoferm 61, and Novozym 33095) and three enzyme concentrations as depectinization processes to produce clear lemon juice and concentrates. In addition, according to the data obtained in laboratory conditions, the most appropriate process was carried out in production lines of fruit juice plant (Anadolu Etap Inc.) in our region (Çukurova, Turkey). In this plant, clarified lemon juice was produced. Effects of the processing steps on some quality parameters were investigated during the lemon juice production and the obtained concentrates were stored at $-25^{\circ} \mathrm{C}$ for 180 days.

\section{Materials and Methods}

\subsection{Production of Clarified Lemon Juices in Laboratory Scale}

2.1.1. Juice Processing. Lemons (Interdonato) were purchased from a local market (Adana, Turkey) and were washed

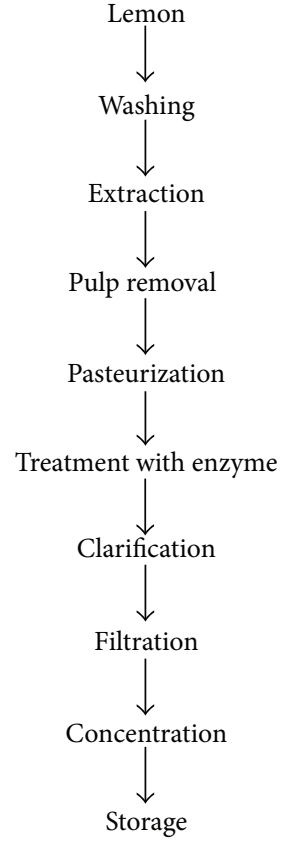

Figure 1: Production of clear lemon juice.

with tap water to remove surface dirt. The lemon juice was extracted by a citrus extractor machine (Can Can, Citrus Extractor Machine, Turkey) and then rapidly strained through a stainless steel sieve with pore diameter of $3 \mathrm{~mm}$ to accomplish separation of most of the suspended matter from lemon juice. The lemon juice was pasteurized at $75^{\circ} \mathrm{C}$ for $15 \mathrm{~s}$ and enzymatically treated with pectolytic enzyme preparation at $35^{\circ} \mathrm{C}$.

2.1.2. Enzymatic Treatment of Lemon Juice. In this study, for the production of clear lemon juice (Figure 1), enzymes obtained from different companies, Rapidase Intense (DSM Food Specialties, Beverage Ingredients, The Netherlands), Novoferm 61, and Novozym 33095 (Novozyms, Bagsvaerd, Denmark), were used. The enzymes were treated in a laboratory scale stainless steel tank at $35 \pm 2{ }^{\circ} \mathrm{C}$ and stirred with constant velocity $(65 \mathrm{rev} / \mathrm{min})$. Each of the enzymes was added to the tank at a concentration of $10 \mu \mathrm{L} / 100 \mathrm{~mL}$, $20 \mu \mathrm{L} / 100 \mathrm{~mL}$, and $40 \mu \mathrm{L} / 100 \mathrm{~mL}(100,200$, and $400 \mathrm{~mL} /$ ton, resp.). Pectolytic enzyme preparations were used to break down dissolved pectin in raw lemon juice. Breaking down dissolved pectin by pectolytic enzyme preparation provides better clarification for the production of clear fruit juice by releasing protein molecules attached to pectin molecules. Breakdown of pectin was observed with alcohol test in 15minute intervals. Following enzymatic treatment, the next step was applied to the lemon juice clarification process.

2.1.3. Clarification of Lemon Juice. After reaching each incubation time $\left(35^{\circ} \mathrm{C}, 15 \mathrm{~min}-165 \mathrm{~min}\right)$ the enzyme treated lemon juices were immediately heated at $50^{\circ} \mathrm{C}$. Bentonite, gelatin, and kieselsol having negative, positive, and negative charges, respectively, were added to lemon juice for clarification. Bentonite (SIHA-Puranit UF), gelatin (SIHA-Gelatin 
Fine Granules type A, 80-100 bloom), and kieselsol (Levasil 200, $\mathrm{SiO}_{2}, 30 \%$ Food Grade) were supplied by Targid Inc. (Turkey). Preliminary experiments were carried out for the amounts of bentonite (5\%), gelatin (1\%), and kieselsol (Levasil $200 / 30 \%$ ) which were determined as $35 \mathrm{~L} /$ ton, $2 \mathrm{~L} /$ ton, and $2 \mathrm{~L} /$ ton lemon juice, respectively. The lemon juice was incubated $\left(35^{\circ} \mathrm{C}\right)$ for 2 hours by mixing $5 \mathrm{~d}(110 \mathrm{rev} / \mathrm{min})$. Initially, to ensure homogeneous distribution, the fining agents were stirred and then were incubated for aggregation without stirring.

The clarification of the lemon juice was carried out using laboratory scale filtration unit with filter paper plate (MinifiltroF6, $200 \times 200 \mathrm{~mm}$, Enotecnica Pillan Snc, Italy). Clarified lemon juices were concentrated in a rotary evaporator under vacuum (Heidolph Basic Eei-VAP HL, Germany) at $60^{\circ} \mathrm{C}$. The clarified juice was concentrated using a rotary vacuum evaporator until it reached about $45^{\circ}$ brix. Each experiment was carried out in three replications. Samples of concentrate clear lemon juice were stored at $-25^{\circ} \mathrm{C}$ for 180 days in brown bottles and were analyzed in two-month intervals.

2.1.4. Production of Lemon Juice in Fruit Juice Plant. As a result of the data obtained from laboratory results, considering both amount of enzymes used and enzymation time, the best appropriate enzymation conditions were carried out in production lines of fruit juice plant (Anadolu Etap Inc.) in our region (Çukurova, Turkey). In this plant, clarified lemon juice was produced by using Novozym $33095(200 \mathrm{~mL} / \mathrm{ton}$ $(20 \mu \mathrm{L} / 100 \mathrm{~mL}))$ at $35^{\circ} \mathrm{C}$. Enzymation was carried out in a 6ton tank, for $30 \mathrm{~min}$. Clarification fining agents were added in amounts of bentonite (5\%), gelatin (1\%), and kieselsol (Levasil $200 / 30 \%$ ) which were determined as $35 \mathrm{~L} /$ ton, $2 \mathrm{~L} /$ ton, and $2 \mathrm{~L} /$ ton lemon juice, respectively.

In the production of clear lemon juice concentrate, the production stages were extraction, pulp removing, pasteurization, enzymation, clarification, filtration (rotary vacuum filter, kieselguhr filter, and paper filter), and evaporation (T.A.S.T.E. evaporator, $95^{\circ} \mathrm{C}, 700 \mathrm{mmHg}$ under vacuum), respectively. Samples from production stages were taken three times. All concentrate samples were stored at $-25^{\circ} \mathrm{C}$ for 180 days in brown bottles and were analyzed in two-month intervals.

Lemon juice concentrates (concentrate samples were diluted to $9^{\circ}$ brix and then analyses were made) produced in the laboratory and in the factory were subjected to the following analyses.

2.2. Determination of Turbidity. The turbidity of the clarified lemon juices was determined using a portable turbidimeter (WTW Turb550, Germany) and results were reported in nephelometric turbidity units (NTU).

2.3. Determination of Viscosity. The viscosity of clarified lemon juices was determined using a Brookfield viscometer (Model DV-II+Pro, Brookfield Engineering Laboratory Inc., Middleboro, USA) at $100 \mathrm{rpm}$ with spindle 62.

2.4. Determination of Pectin Degradation (Alcohol Test). Alcohol test was used to verify pectin degradation after enzyme treatment. This test was used both for process control and for determining the optimum enzyme dosage. Two 176 volumes $(10 \mathrm{~mL})$ of acidified ethanol (add $1 \mathrm{~mL}$ of $37 \%$ hydrochloric acid to $100 \mathrm{~mL}$ of $96 \% 177$ ethanol) were added to one volume $(5 \mathrm{~mL})$ of lemon juice. For each sample, breakdown of pectin was observed with alcohol test in 15minute intervals [17].

2.5. Determination of Total Pectin Content. Total pectin in the clear lemon juice samples was determined according to the method described by List et al. [18]. Standard graphics were prepared as $10,20,30,40,50,60$, and $70 \mu \mathrm{g} / \mathrm{mL}$ from galacturonic acid anhydride.

2.6. Determination of PME Activity. PME activity of the sample was carried out by modifying the method of Kimball [19]. For the measurement of PME activity, $10 \mathrm{~mL}$ of lemon juice was mixed with $20 \mathrm{~mL}$ of $1 \%$ pectin-salt substrate $(0.1 \mathrm{M}$ $\mathrm{NaCl}$ ) and incubated at $30^{\circ} \mathrm{C}$ during analysis. The solution was adjusted to $\mathrm{pH} 7.0$ with $2.0 \mathrm{~N} \mathrm{NaOH}$ and then the $\mathrm{pH}$ of solution was readjusted to $\mathrm{pH} 7.7$ with $0.05 \mathrm{~N} \mathrm{NaOH}$. After the $\mathrm{pH}$ reached 7.7, $0.10 \mathrm{~mL}$ of $0.05 \mathrm{~N} \mathrm{NaOH}$ was added. Time was measured $\left(t^{\prime}\right)$ until $\mathrm{pH}$ of the solution regained $\mathrm{pH}$ of 7.7. PME activity (\%) was calculated by the following formulas, where $\left(t^{\prime}\right)$ is time in min, $A_{0}$ is PME activity of the untreated sample which was determined immediately after processing to avoid the effects of storage time, and $A_{t}$ is PME activity after the treatments. PME activity $(A)$ was calculated by the following equation:

$$
\begin{aligned}
& A=\frac{(0.05 N-\mathrm{NaOH}) \cdot(0.10 \mathrm{~mL}-\mathrm{NaOH})}{\left(t^{\prime}\right)(10-\mathrm{mL} \text { sample })}, \\
& \text { Residual PME Activity }(\%)=\left(\frac{A_{t}}{A_{0}}\right) 100 .
\end{aligned}
$$

\section{Results and Discussion}

3.1. Pectin Degradation in Lemon Juices. Pectin degradation was observed during depectinization with the alcohol test in 15-minute intervals. In figures (Figures 2, 3, and 4) belonging to enzymation, $(+)$ sign means that enzymation is still in progress, (o) sign means enzymation is undecided case, and $(-)$ sign means enzymation is over.

Rapidase Intense. In enzyme applications, in the samples of $10 \mu \mathrm{L} / 100 \mathrm{~mL}$ concentrations, undecided case started at the end of 120 minutes and at the end of 135 minutes negative results were obtained. In the samples of $20 \mu \mathrm{L} / 100 \mathrm{~mL}$ concentration, undecided case started at the end of 60 minutes and negative results were obtained at the end of 75 minutes. In the samples of $40 \mu \mathrm{L} / 100 \mathrm{~mL}$ concentration, undecided case started at the end of 30 minutes and negative results were obtained at the end of 45 minutes (Figure 2).

Novoferm 61. In enzyme applications, in the samples of $10 \mu \mathrm{L} / 100 \mathrm{~mL}$ concentrations, undecided case started at the end of 150 minutes and at the end of 165 minutes negative results were obtained. In the samples of $20 \mu \mathrm{L} / 100 \mathrm{~mL}$ concentration, undecided case started at the end of 60 minutes 


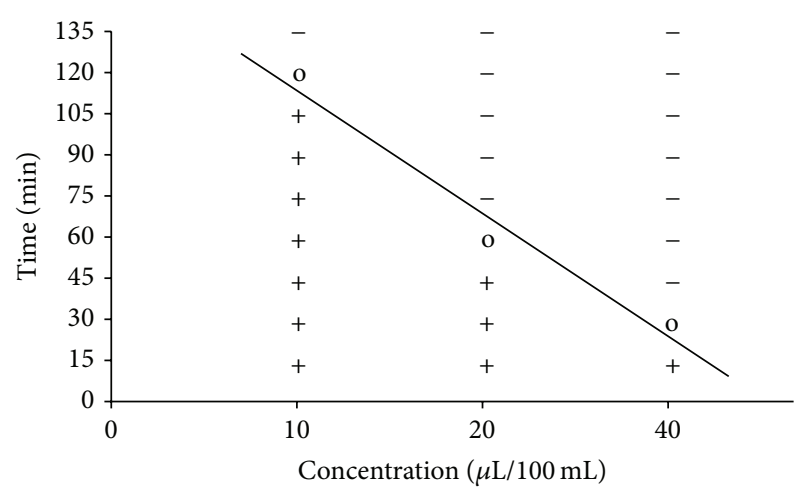

FIGURE 2: Rapidase Intense enzyme application (enzymation is still in progress $(+)$, undecided case (o), and over $(-))$.

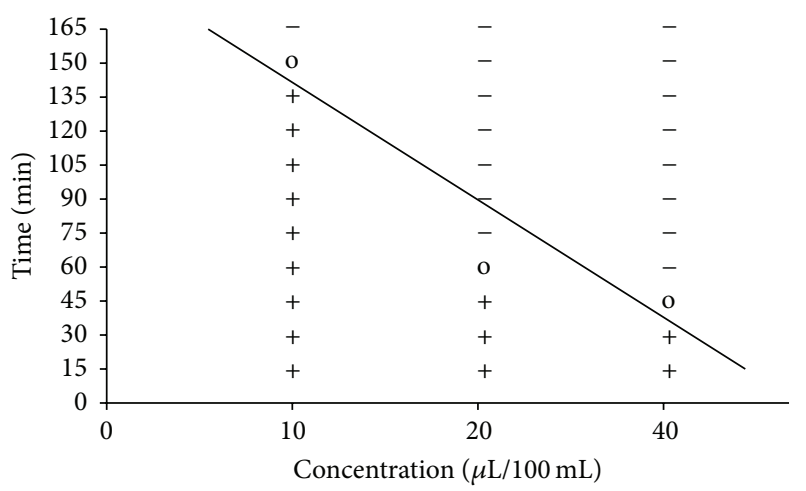

FIGURE 3: Novoferm 61 enzyme application (enzymation is still in progress $(+)$, undecided case $(o)$, and over $(-))$.

and negative results were obtained at the end of 75 minutes. In the samples of $40 \mu \mathrm{L} / 100 \mathrm{~mL}$ concentration, undecided case started at the end of 45 minutes and negative results were obtained at the end of 60 minutes (Figure 3 ).

Novozym 33095. In enzyme application, in the test results of $10 \mu \mathrm{L} / 100 \mathrm{~mL}$ concentrations, undecided case started at the end of 60 minutes and at the end of 75 minutes negative results were obtained. In the samples of $20 \mu \mathrm{L} / 100 \mathrm{~mL}$ concentration, negative results were obtained at the end of 30 minutes. In the samples of $40 \mu \mathrm{L} / 100 \mathrm{~mL}$ concentration, negative results were obtained at the end of 15 minutes (Figure 4).

According to the findings obtained from pectin degradation, Novozym 33095 degraded the pectin in lemon most quickly. The highest concentration of this enzyme achieved pectin degradation in less than 15 minutes. Novozym 33095 was determined as the most effective enzyme for depectinization followed by Novoferm 61 and Rapidase Intense. When selecting an enzyme for depectinization in fruit juice industry, economic as well as rapid activity should be required. When enzymation occurs slowly, important quality losses can be brought about due to oxidation and unwanted fermentation. For this reason, fruit juice companies are obliged to determine enzyme and dosage, between pectin degradation

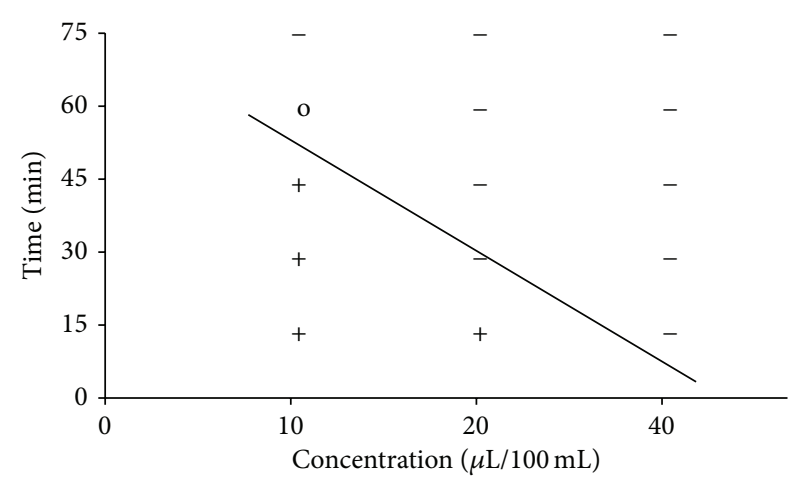

Figure 4: Novozym 33095 enzyme application (enzymation is still in progress (+), undecided case (o), and over $(-))$.

speed of enzyme and economy of the enzyme which will provide a balance without compromising on quality.

3.2. Total Pectin Contents of Lemon Juices. As shown in Table 1, after extraction, total pectin contents of lemon juices ranged from 116.45 to $121.77 \mathrm{GA}-\mathrm{AH} \mathrm{mg} / \mathrm{L}$. For each of the three enzyme applications, after pulp separation process, reductions of total pectin contents were found statistically significant $(P<0.01)$. Amount of total pectin contents after pulp separation process ranged from 103.64 to 106.15 GA$\mathrm{AH} \mathrm{mg} / \mathrm{L}$. Reduction of total pectin contents was considered to be expected because of using a $3 \mathrm{~mm}$ stainless steel sieve in pulp separation process. Increases were determined in total pectin content with pasteurization. But changes of total pectin contents were found statistically insignificant between the pulp separation and pasteurization treatments. Demirdöven and Baysal [20] studied optimization of ohmic heating applications for pectinmethylesterase inactivation in orange juice and found $410.3 \pm 1.1 \mathrm{GA}-\mathrm{AH} \mathrm{mg} / \mathrm{L}$ pectin content at $95^{\circ} \mathrm{C}$ for $60 \mathrm{~s}$ application. In our examples, similar slight increases were determined with pasteurization. After the enzyme treatment, total pectin contents decreased rapidly and were determined to be 3.00-15.80 GA-AH mg/L for Rapidase, 9.38-29.17 GA-AH for Novoferm, and $61 \mathrm{mg} / \mathrm{L}$ and $0.00-0.00 \mathrm{GA}-\mathrm{AH} \mathrm{mg} / \mathrm{L}$ for Novozym 33095. It was thought that all of the enzymes at this stage resulted in the expected performance. Novozym 33095 degraded pectin in lemon juice better than the other two enzymes. Increasing the enzyme concentration caused more decrease in total pectin contents. Pectin was not determined in clarification and filtration stages for the different concentrations of the three enzymes.

In the factory, total pectin content of clear lemon juice produced by Novozym 33095 was determined to be 132.13 GA-AH mg/L in extraction stage, 80.52 GA-AH mg/L in pulp separation stage, and $68.62 \mathrm{GA}-\mathrm{AH} \mathrm{mg} / \mathrm{L}$ in pasteurization stage. A decrease in the total pectin content in the pulp separation stage was higher than in laboratory production, which could be related to a more effective pulp separation process with the three-stage finisher systems that the factory used. Decreasing the total pectin content in pasteurization stage was found to be statistically significant $(P<0.01)$. 


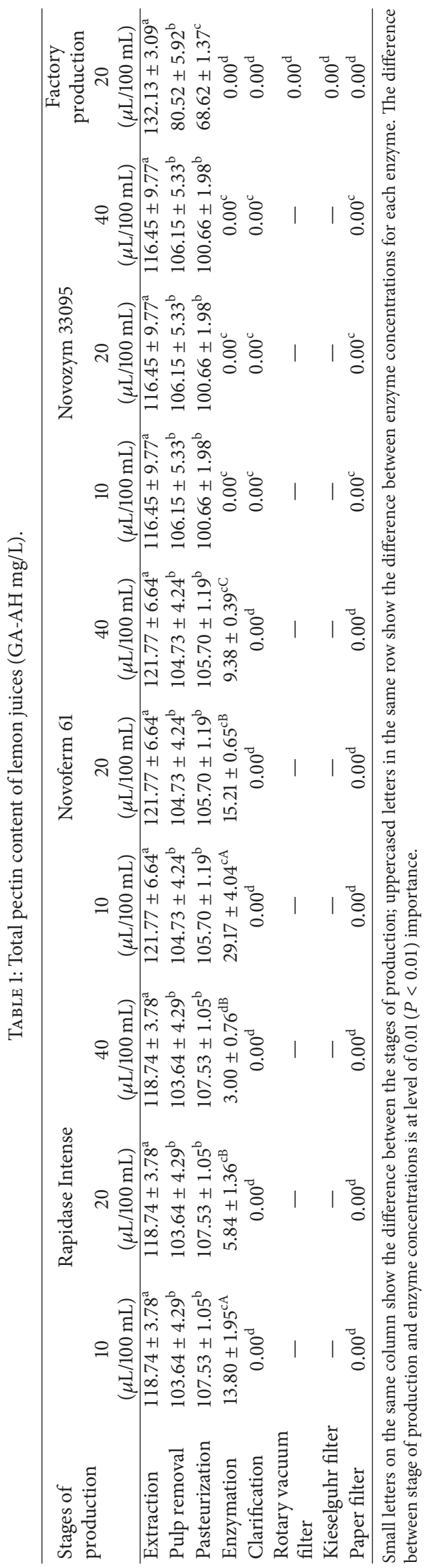


Total pectin was not determined in the enzyme treatment until the end of paper filter stage. $20 \mu \mathrm{L} / 100 \mathrm{~mL}$ concentration of Novozym 33095 used in the plant was also carried out successfully in the depectinization and clarification processes (Table 1).

Both clear lemon juice concentrates were produced in laboratory and in factory. Total pectin analyses were carried out every two months during the 180 -day storage but pectin was not determined.

Wang et al. [21] studied quantitation of bioactive compounds in citrus fruits cultivated in Taiwan and determined total pectin and water-soluble pectin in the edible portions of lemon and found $60.6 \pm 2.67(\mathrm{mg} / \mathrm{g}$, db) total pectin content and $31.2 \pm 1.07(\mathrm{mg} / \mathrm{g}, \mathrm{db})$ water-soluble pectin content, respectively.

3.3. Viscosity Values of Lemon Juices. As shown in Table 2, viscosity values after extraction of lemon juices ranged from 26.90 to $29.22 \mathrm{cP}$ in laboratory production. After pulp separation, decreasing the viscosity for each of the three enzyme applications was determined to be statistically significant $(P<0.01)$. After pulp separation, values of viscosity ranged from 21.30 to $25.89 \mathrm{cP}$. Rough particles of pulp (membrane particles of segment, particles of the central axis, sacs and particles, and particles detached from kernel and albedo) were removed using $3 \mathrm{~mm}$ stainless steel sieve in pulp separation process, so values of viscosity decreased. Value of viscosity in the samples of $40 \mu \mathrm{L} / 100 \mathrm{~mL}$ concentration decreased more than the other concentrations at the depectinization stage. At this stage, viscosity values of changes in Rapidase Intense and Novoferm 61 application were found statistically significant in different enzyme concentrations $(P<0.01)$. The largest decrease in the viscosity values was determined in filtration with removal of elements of turbidity as expected $(P<0.01)$. Viscosity values of clear lemon juices in filtration ranged from 15.10 to $17.44 \mathrm{cP}$ at laboratory production. Upon enzyme treatment, degradation of pectin leads to a reduction of water holding capacity. Free water is released to the system and hence, the viscosity of the juice is reduced. Therefore, to enhance filtration process performance, fruit juices are usually pretreated with enzyme, before filtration, for the purpose of hydrolysing soluble polysaccharides responsible for high viscosity $[22,23]$.

Viscosity values of lemon juice samples in factory production are shown in Table 2. Viscosity values in factory were much lower than our laboratory production at the pulp separation stage because plant has a more effective pulp separation system than our sieve. After the pasteurization stage, changing of viscosity was found insignificant. In the output of paper filter, viscosity value was decreased to $16 \mathrm{cP}$. SánchezMoreno et al. [24] reported that viscosity value of fresh orange juices was found to be $27.78 \mathrm{cp}$ and that of pasteurized $\left(90^{\circ} \mathrm{C} / 1 \mathrm{~min}\right)$ orange juices was found to be $17.93 \mathrm{cP}$. Esteve et al. [25] investigated the effect of storage period under variable conditions on the chemical and physical composition and color of Spanish refrigerated orange juices. They reported viscosity values ranging from 24.3 to $31.3 \mathrm{mPa} / \mathrm{s}$.

Viscosity values of clear lemon juice concentrates at laboratory production were determined and the numbers ranged from 33.10 to $35.87 \mathrm{cP}$ during storage (Table 3). Viscosity values of clear lemon juice concentrates ranged from 32.10 to $33.40 \mathrm{cP}$ in factory production. In both laboratory and factory production, changes in viscosity value of concentrate samples were determined to be statistically insignificant during storage. Also, in lemon juice concentrates produced in the laboratory using different enzymes, concentrations in each storage period of the changes were not statistically significant.

3.4. Turbidity Values of Lemon Juice. Turbidity values of clear lemon juice are given in Table 4. After the extraction stage, NTU values of lemon juices ranged from 1075.05 to 1041.15 in laboratory production. There was no significant change from extraction process to enzymation process in NTU values. After the clarification stage, NTU values were found to decrease significantly $(P<0.01)$ and ranged from 9.75 to 23.07. Values of NTU at clarification stage were higher than the filtration stage due to addition of fining agents. After the filtration stage, NTU values were again decreased and ranged between 0.28 and 0.36 . NTU values of filter examples were determined to be $0.28-0.32$ by using Rapidase Intense, $0.29-0.35$ by using Novoferm 61, and $0.31-0.36$ by using Novozym 33095 (Table 4).

NTU values of clear lemon juice treated with Novozym $33095(20 \mu \mathrm{L} / 100 \mathrm{~mL})$ produced in the factory ranged from 733 to 1051.67 , from extraction stage to clarification stage. In factory, after addition of fining agents, lemon juice was given direct rotary vacuum filter without holding in clarification stage. Therefore, the NTU value in clarification stage increased. Value of NTU was measured to be 10.60 , 2.57, and 0.01 at end of rotary vacuum filter, kieselguhr, and paper filter, respectively. NTU values produced in the factory were determined to be lower than those produced in the laboratory. The three-stage filtration was thought to lead to such a result.

NTU values of all samples of clear lemon juice concentrates were increased at the storage and this increase was found statistically significant $(P<0.01, P<0.05)$.

NTU values of clear lemon juice concentrates ranged from 0.21 to 0.58 by applying Rapidase Intense, ranged from 0.29 to 0.66 by applying Novoferm 61, and ranged from 0.18 to 0.51 by applying Novozym 33095 (Table 5). The lowest NTU values were found to be $40 \mu \mathrm{L} / 100 \mathrm{~mL}$ in Novozym 33095 application. Although, NTU values of clear lemon juice samples produced in our study were increased with concentration and storage, NTU value was determined to be less than reported 0.0-1.0 bright clear and crystal clear juice. Also, NTU value of diluted concentrate is unaccepted more than 2.0 at international trade of apple juice concentrate [2628].

3.5. PME Activity Values of Lemon Juice. Residual PME activity of lemon juices after the pulp separation was determined to decrease between 81.77 and $88.15 \%$ (Table 6). Residual PME activity of each of the three enzymes and their concentrations together with production stages was observed to decrease. The difference between the stages of production was found to be statistically significant $(P<0.01)$. Enzymatic 


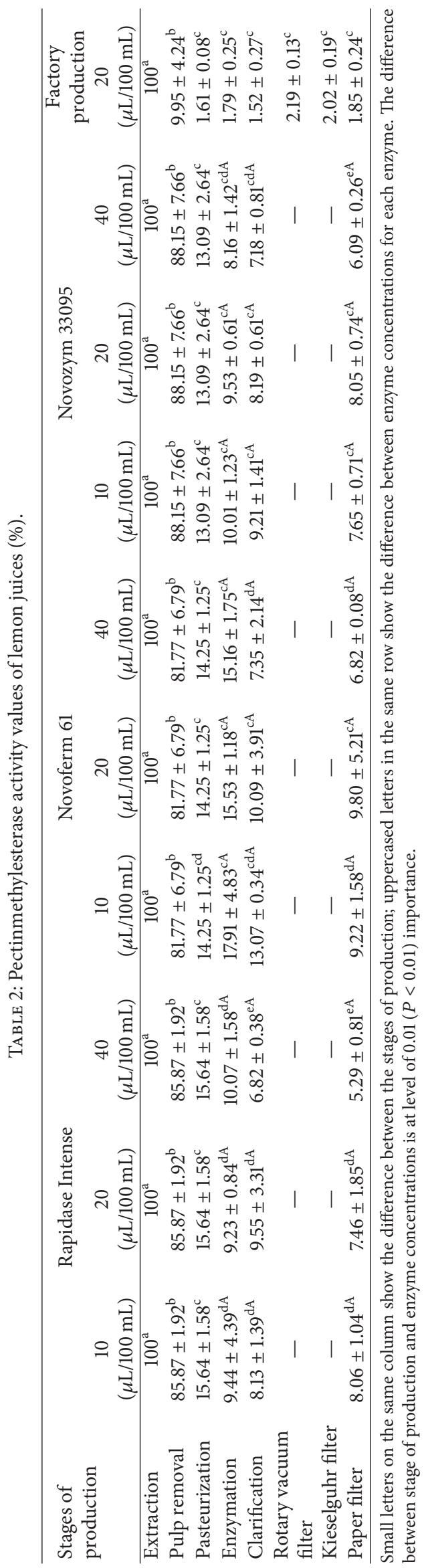




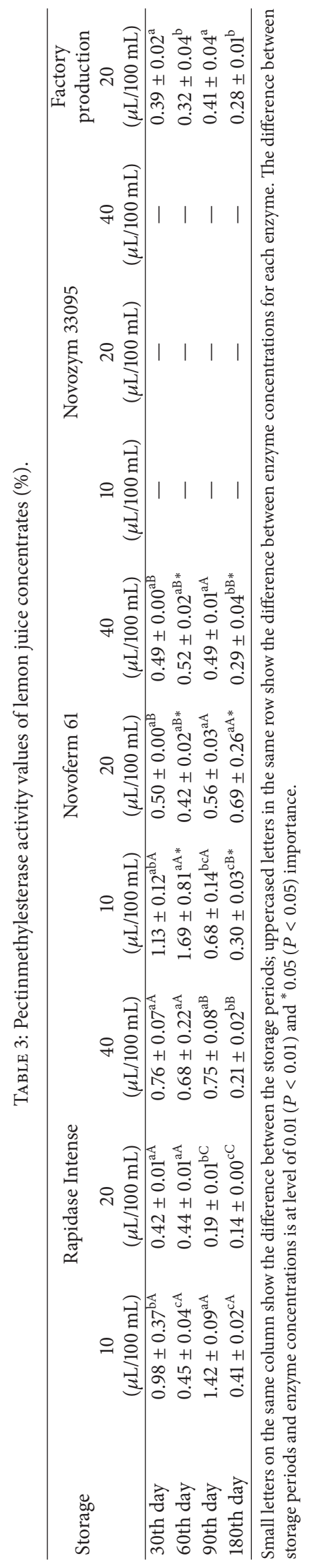




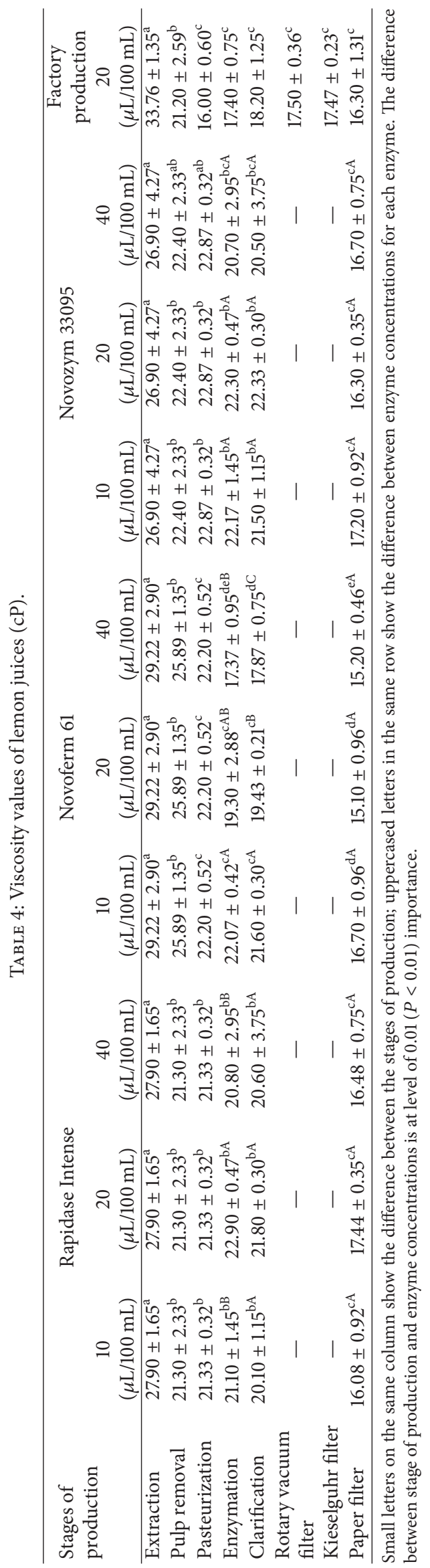




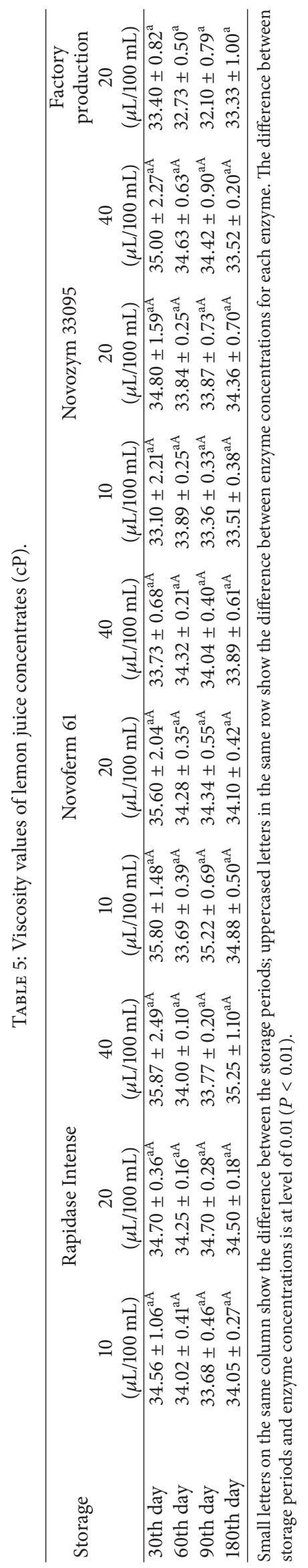




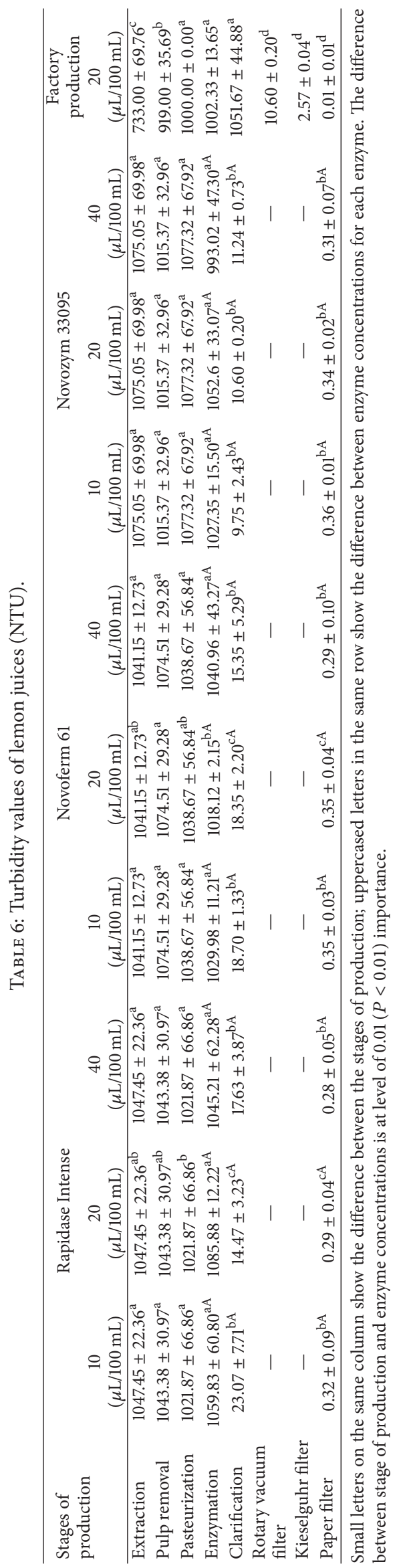




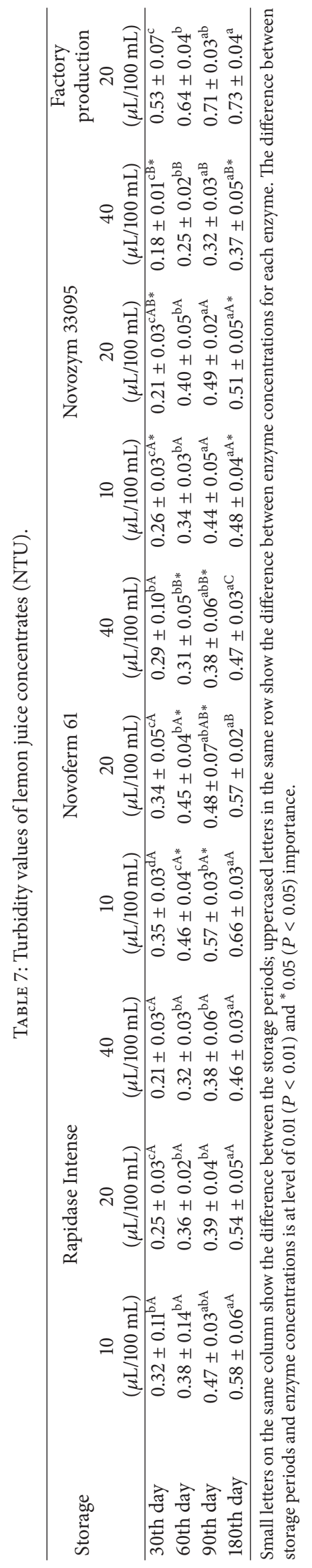


application in different concentrations of each enzyme and the difference between residual PME activity at enzymation, clarification, and filtration stages were determined to be insignificant. After the filtration stages, residual PME activity ranged from 5.29 to $9.80 \%$ in laboratory. In factory, residual PME activity was significantly decreased after pulp separation stage due to an effective pulp separation with three-stage finisher system and was determined to be $9.95 \%$. With pasteurization, this value decreased to $1.61 \%$. Residual PME activity at end of paper filter was determined to be $1.85 \%$.

According to the findings of the residual activity of PME, in both laboratory and factory productions, an increase in residual PME activity was not observed at the enzyme treatment. These findings indicated that there was not PME activity in enzyme solutions obtained from different manufacturing companies. In the case of PME, an increase might have been expected but no increase was observed in the application of each of the enzymes in the enzyme treatment.

Residual PME activity of clear lemon juice concentrates ranged from 0.21 to $1.69 \%$ during storage (Table 7). PME activity of clear lemon juices decreased to significant levels together with the concentration process. This can be explained through heating load and changing with proportional increasing of acidity level during the concentration process in isoelectric point of the lemon juice. Enzymes are protein structures, which quickly react to changes in isoelectric points in lemon juice.

Changing of residual PME activity was found to be significant $(P<0.01)$ in Rapidase and Novoferm 61 applications during storage. But these changes were in small amounts. Although residual PME activity analyses of concentrates obtained from Novozym 33095 application were done every two months during six-month storage, residual PME activity was not observed. In concentrates of clear lemon juice produced in factory, residual PME activity values ranged from 0.28 to $0.41 \%$ and were significantly $(P<0.01)$ different.

Pectinmethylesterase (PME) is an enzyme of major impact on orange juice processing because of its effect on clarification of orange juice or gelation of concentrated orange juice $[19,29]$. Determination of residual PME activity level reveals important information about the stability of the product [30]. Polydera et al. [31] applied the heat treatment to orange juice at $80^{\circ} \mathrm{C}$ for $60 \mathrm{~s}$ and inactivated $95 \%$ of orange juice PME. It has been reported that enzymatic activity of residual PME is heat-resistant isoenzymes which were not inactivated even at higher temperatures. PME is more thermally resistant than vegetative spoilage microorganisms [32]. Sentandreu et al. [33] reported that residual PME activity was determined to be about $20 \%$ residual PME activity in heattreated samples (mandarin and orange) at $75^{\circ} \mathrm{C}$ for 5,10 , and $20 \mathrm{~s}$ and at $80^{\circ} \mathrm{C}$ for 5 and $10 \mathrm{~s}$. Taking into consideration the results of the sensory and residual enzyme analysis, heat treatment at $85^{\circ}$ for $\mathrm{C} 10 \mathrm{~s}$ was found to be an appropriate application.

\section{Conclusions}

According to the findings obtained from pectin degradation, Novozym 33095 degraded the pectin in lemon most quickly. The highest concentration of this enzyme achieved pectin degradation in less than 15 minutes. For each of the three enzyme applications, after pulp separation process, reductions in the total pectin contents were observed. Pectin was not determined in clarification and filtration stages for the different concentrations of the three enzymes. For both clear lemon juice concentrates produced in laboratory and in factory, total pectin analyses were carried out every two months during 180-day storage, but pectin was not determined. After pulp separation and filtration stages, the largest decrease in the viscosity values was determined at laboratory production of clear lemon juice. Values of viscosity were determined to display significant decrease in pulp separation and pasteurized samples. NTU values of filter examples were determined to be $0.28-0.32$ by using Rapidase Intense, $0.29-0.35$ by using Novoferm 61 , and $0.31-0.36$ by using Novozym 33095. NTU values of all samples of clear lemon juice concentrate increased during storage. NTU values of clear lemon juice samples produced in our study increased with concentration and storage. Residual PME activity of each of the three enzymes and their concentrations together with production stages was observed to decrease. At the end of filtration, in $40 \mu \mathrm{L} / 100 \mathrm{~mL}$ concentrations of each of the three enzymes, values of residual PME activity were found to be in the lowest quantities. PME activity of clear lemon juice samples was determined to decrease together with storage. In clear lemon juice concentrates produced by using Novozym 33095, residual PME activity was not observed.

\section{Conflict of Interests}

The authors declare that there is no conflict of interests regarding the publication of this paper.

\section{Acknowledgment}

This study was supported by The Scientific and Technological Research Council of Turkey (TUBITAK) (Project no. TOVAG-110O786).

\section{References}

[1] Q. Mu, X. Sun, G. Zhong, X. Wang, C. Song, and J. Fang, "Employment of a new strategy for identification of lemon Citrus limon L. cultivars using RAPD markers," African Journal of Agricultural Research, vol. 714, pp. 2075-2082, 2012.

[2] Faostat, "Food and agriculture organization of the united nations. Food and agricultural commodities production," 2013, http://faostat.fao.org/site/339/default.aspx.

[3] V. Shrivastava, L. Purwal, and U. K. Jain, "In vitro Pediculicidal activity of juice of Citrus limon," International Journal of PharmTech Research, vol. 2, no. 3, pp. 1792-1795, 2010.

[4] C. Dhuique-Mayer, C. Caris-Veyrat, P. Ollitrault, F. Curk, and M.-J. Amiot, "Varietal and interspecific influence on micronutrient contents in citrus from the mediterranean area," Journal of Agricultural and Food Chemistry, vol. 53, no. 6, pp. 2140-2145, 2005.

[5] L. W. Morton, R. A.-A. Caccetta, I. B. Puddey, and K. D. Croft, "Chemistry and biological effects of dietary phenolic compounds: relevance to cardiovascular disease," Clinical and 
Experimental Pharmacology and Physiology, vol. 27, no. 3, pp. 152-159, 2000.

[6] N. Pellegrini, M. Serafini, B. Colombi et al., "Total antioxidant capacity of plant foods, beverages and oils consumed in Italy assessed by three different in vitro assays," Journal of Nutrition, vol. 133, no. 9, pp. 2812-2819, 2003.

[7] E. González-Molina, A. Gironés-Vilaplana, P. Mena, D. A. Moreno, and C. Garcia-Viguera, "New beverages of lemon juice with elderberry and grape concentrates as a source of bioactive compounds," Journal of Food Science, vol. 77, pp. 6727-6733, 2012.

[8] N. Martí, A. Pérez-Vicente, and C. García-Viguera, "Influence of storage temperature and ascorbic acid addition on pomegranate juice," Journal of the Science of Food and Agriculture, vol. 822, pp. 217-221, 2001.

[9] D. Saura, N. Marti, M. Valero, E. González, A. Carbonell, and J. Laencina, "Separation of aromatics compounds during the clarification of lemon juice by cross-flow filtration," Industrial Crops and Products, vol. 36, no. 1, pp. 543-548, 2012.

[10] D. Saura, J. Laencina, A. J. Pérez-López, V. Lizama, and A. A. Carbonell-Barrachina, "Aroma of canned peach halves acidified with clarified lemon juice," Journal of Food Science, vol. 68, no. 3, pp. 1080-1085, 2003.

[11] D. Saura, N. Martí, J. Laencina, V. Lizama, and A. A. CarbonellBarrachina, "Sensory evaluation of canned peach halves acidified with clarified lemon juice," Journal of Food Science, vol. 69, no. 2, pp. snq74-snq78, 2004.

[12] P. Rai and S. De, "Clarification of pectin-containing juice using ultrafiltration," Current Science, vol. 96, no. 10, pp. 1361-1371, 2009.

[13] A. R. Nur 'aliaa, M. K. S. Mazlina, and F. S. Taip, "Impact of commercial pectolytic enzymes on selected properties of white dragon fruit juice," Journal of the Institution of Engineers, vol. 714, pp. 25-31, 2010.

[14] S. G. E. Giap, "The hidden property of arrhenius-type relationship: viscosity as a function of temperature," Journal of Physical Science, vol. 211, pp. 29-39, 2010.

[15] B. K. Tiwari, K. Muthukumarappan, C. P. O’Donnell, and P. J. Cullen, "Inactivation kinetics of pectin methylesterase and cloud retention in sonicated orange juice," Innovative Food Science and Emerging Technologies, vol. 10, no. 2, pp. 166-171, 2009.

[16] I. Alkorta, C. Garbisu, M. J. Llama, and J. L. Serra, "Industrial applications of pectic enzymes: a review," Process Biochemistry, vol. 33, no. 1, pp. 21-28, 1998.

[17] F. Will, "Fruchtsaftkolloide: einfluss auf die ultrafiltration und den alkoholtest. Möglichkeiten zur Abreicherung in klaren Saften," Flüssiges Obst, vol. 60, pp. 360-364, 1993.

[18] D. List, S. Buddruß, and M. Bodtke, "Pectinbestimmung mit meta-phenylphenol," Zeitschrift Für Lebensmittel-Untersuchung und Forschung, vol. 180, no. 1, pp. 48-52, 1985.

[19] D. A. Kimball, "Citrus processing," in Quality Control and Technology, Van Nostrand Reinhold, New York, NY, USA, 1991.

[20] A. Demirdöven and T. Baysal, "Optimization of ohmic heating applications for pectin methylesterase inactivation in orange juice," Journal of Food Science and Technology, pp. 1-10, 2012.

[21] Y. C. Wang, Y. C. Chuang, and Y. H. Ku, "Quantitation of bioactive compounds in citrus fruits cultivated in Taiwan," Food Chemistry, vol. 102, no. 4, pp. 1163-1171, 2007.

[22] M. Cheryan and J. R. Alvarez, "Food and beverage industry application," in Membrane Separation, R. D. Noble and S. A. Stern, Eds., 1995.
[23] A. G. Liew Abdullah, N. M. Sulaiman, M. K. Aroua, and M. J. Megat Mohd Noor, "Response surface optimization of conditions for clarification of carambola fruit juice using a commercial enzyme," Journal of Food Engineering, vol. 81, no. 1, pp. 65-71, 2007.

[24] C. Sánchez-Moreno, L. Plaza, P. Elez-Martínez, B. de Ancos, O. Martín-Belloso, and M. P. Cano, "Impact of high pressure and pulsed electric fields on bioactive compounds and antioxidant activity of orange juice in comparison with traditional thermal processing," Journal of Agricultural and Food Chemistry, vol. 53, no. 11, pp. 4403-4409, 2005.

[25] M. J. Esteve, A. Frígola, C. Rodrigo, and D. Rodrigo, "Effect of storage period under variable conditions on the chemical and physical composition and colour of Spanish refrigerated orange juices," Food and Chemical Toxicology, vol. 43, no. 9, pp. 14131422, 2005.

[26] R. Jung and T. Jund, "Filtrationsarten zur filtration von fruchtsaeften-teil 1," Flüssiges Obst, pp. 343-347, 1997.

[27] S. T. D. de Barros, C. M. G. Andrade, E. S. Mendes, and L. Peres, "Study of fouling mechanism in pineapple juice clarification by ultrafiltration," Journal of Membrane Science, vol. 215, no. 1-2, pp. 213-224, 2003.

[28] B. Cemeroglu and F. Karadeniz, "Meyve suyu üretim teknolojisi," in Meyve ve Sebze Isşleme Teknolojisi, B. Cemeroglu, Ed., vol. 1, pp. 297-661, Gida Teknolojisi Dernegi Yayinlari, Ankara, Türkiye, 2004.

[29] S. Basak, H. S. Ramaswamy, and B. K. Simpson, "High pressure inactivation of pectin methyl esterase in orange juice using combination treatments," Journal of Food Biochemistry, vol. 25, no. 6, pp. 509-526, 2001.

[30] O. Kurita, T. Fujiwara, and E. Yamazaki, "Characterization of the pectin extracted from citrus peel in the presence of citric acid," Carbohydrate Polymers, vol. 74, no. 3, pp. 725-730, 2008.

[31] A. C. Polydera, N. G. Stoforos, and P. S. Taoukis, "The effect of storage on the antioxidant activity of reconstituted orange juice which had been pasteurized by high pressure or heat," International Journal of Food Science and Technology, vol. 39, no. 7, pp. 783-791, 2004.

[32] C. S. Chen and M. C. Wu, "Kinetic models for thermal inactivation of multiple pectinesterases in citrus juices," Journal of Food Science, vol. 63, no. 5, pp. 747-750, 1998.

[33] E. Sentandreu, L. Carboneil, J. V. Carboneil, and L. Izquierdo, "Effects of heat treatment conditions on fresh taste and on pectinmethylesterase activity of chilled mandarin and orange juices," Food Science and Technology International, vol. 11, no. 3, pp. 217-222, 2005. 

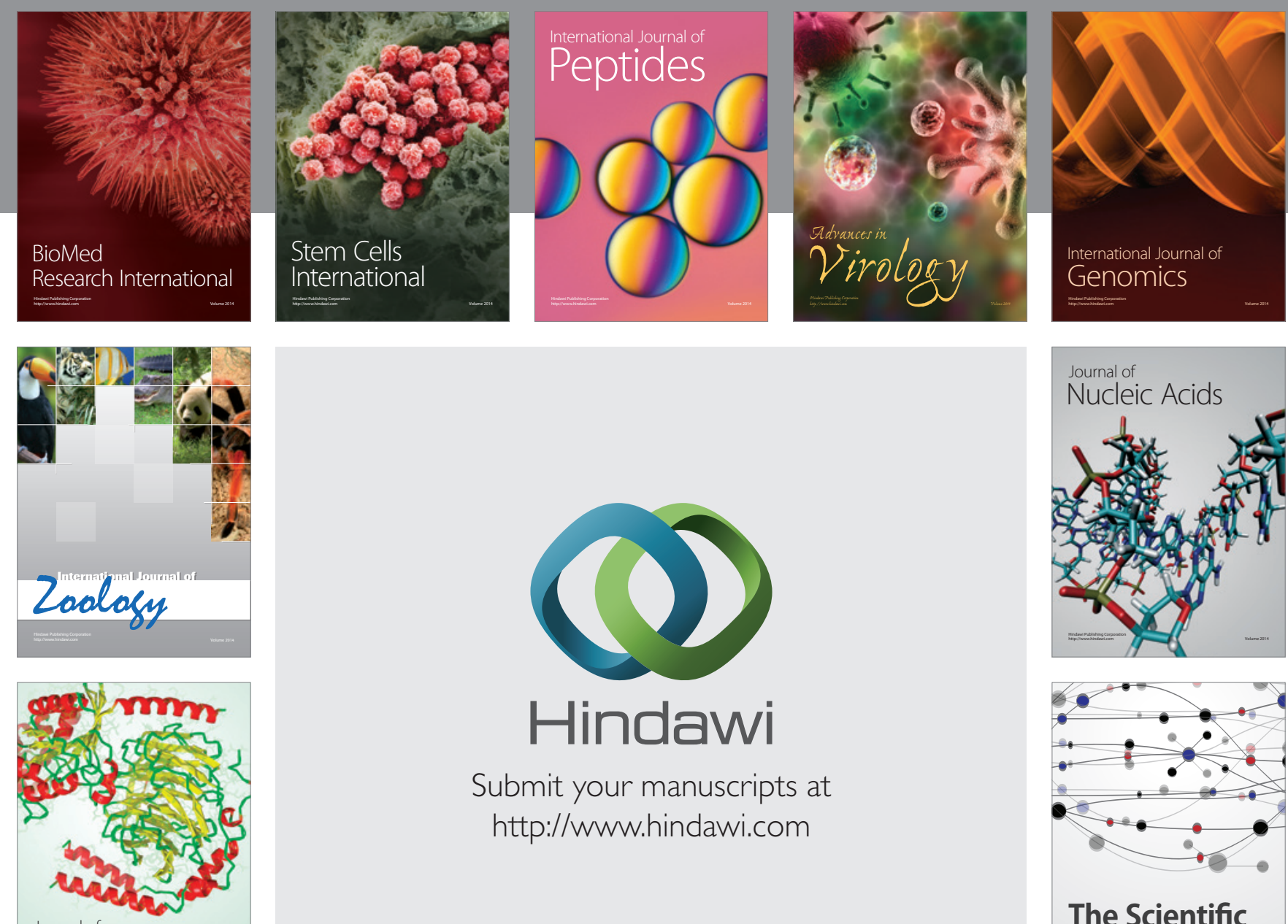

Submit your manuscripts at

http://www.hindawi.com

Journal of
Signal Transduction
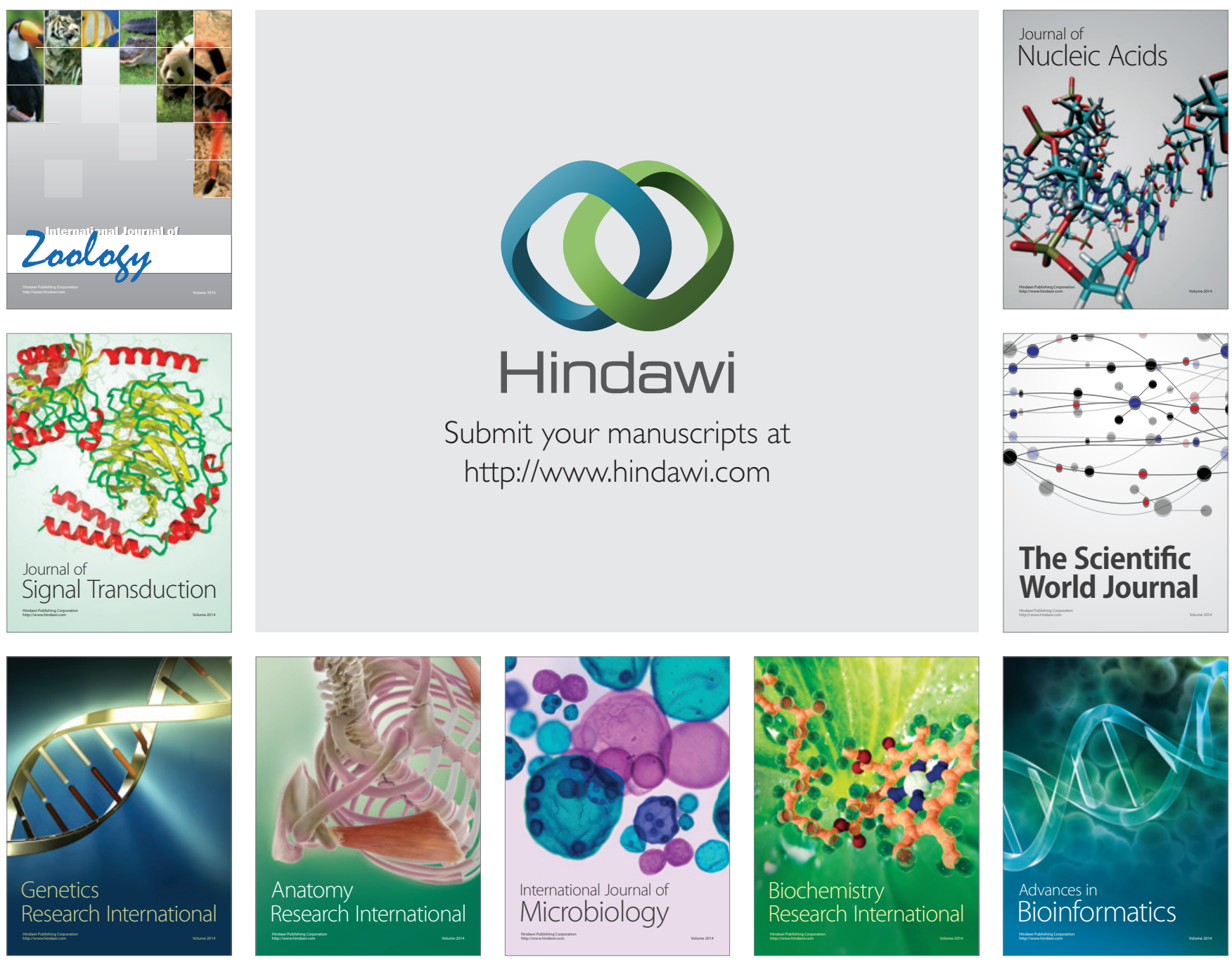

The Scientific World Journal
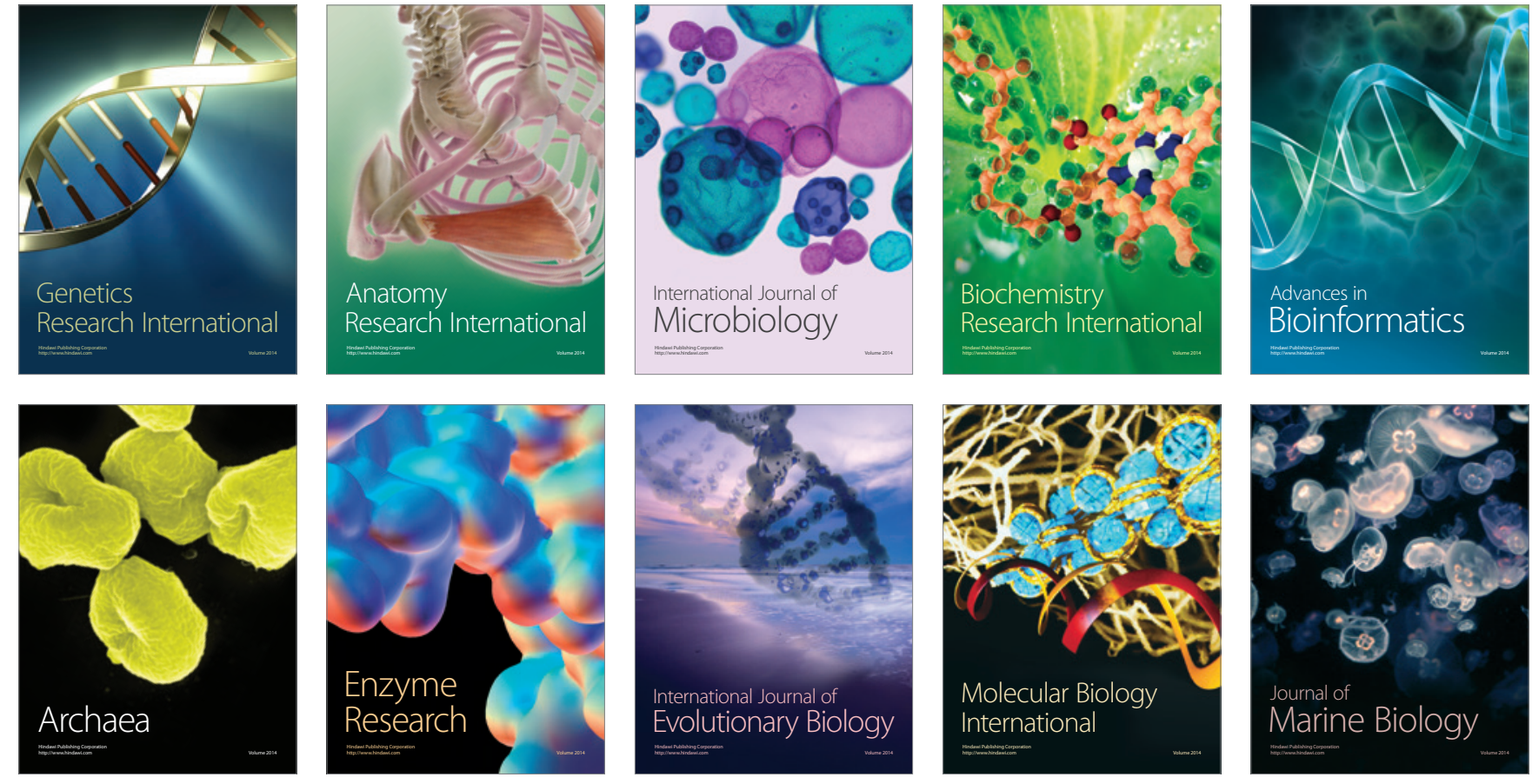